\title{
A Most Unlikely Case: Chile, Pinochet and the ADVANCE OF HUMAN RigHTS
}

\author{
Todd Landman (todd@essex.ac.uk) \\ Department of Government \\ University of Essex
}

This article argues that Chile has had a disproportionate effect on the international politics and law of human rights. Understood in traditional realist terms, Chile is a relatively small country that only recently joined the OECD and that should not have a great deal of impact on international affairs. Yet, for the 40 years since the 1973 military coup that overthrew the government of Salvador Allende it has received a tremendous amount of attention from other states (particularly the United States), inter-governmental organisations and international non-governmental organisations, while at the same time has had a great deal of impact on the public discourse and understanding around human rights in ways that have advanced international law and policy making. The article examines the unlikely nature of Chile's influence on human rights at the international level while recognising that very little true justice has been achieved at the domestic level for the gross violations of human rights that had been committed during the Pinochet dictatorship. The case of Chile is thus an illustrative example of 'the power of human rights' that has contributed to the 'justice cascade' in significant ways, even though true justice at home has been slow in coming.

Keywords: human rights, transitional justice, transnational advocacy, democratic transformation, universal jurisdiction.

\section{Un Caso Improbable: Chile, Pinochet y el Avance DE LOS DERECHOS HuMANOS}

En este artículo se sostiene que Chile ha tenido un efecto desproporcionado en la política y el derecho de los derechos humanos internacionales. Entendido en términos tradicionales realistas, Chile es un país relativamente pequeño que solo recientemente se unió a la OCDE y que no debería tener mucho impacto en los asuntos internacionales. Sin embargo, durante los 40 años desde el golpe militar de 1973 que derrocó al gobierno de Salvador Allende ha recibido una enorme cantidad de atención por parte de otros estados (en particular los Estados Unidos), las organizaciones intergubernamentales y las organizaciones no gubernamentales internacionales, mientras que al mismo tiempo ha tenido una gran repercusión en el discurso público y la comprensión en torno a los derechos humanos en formas 
que han hecho avanzar el derecho internacional y la formulación de políticas. El artículo examina la naturaleza poco probable de la influencia de Chile en materia de derechos humanos a nivel internacional, sin dejar de reconocer que se ha logrado muy poca justicia verdadera a nivel nacional por las graves violaciones de los derechos humanos cometidas durante la dictadura de Pinochet. El caso de Chile es, pues, un ejemplo ilustrativo de "el poder de los derechos humanos" que ha contribuido a la "justicia en cascada" en forma significativa, a pesar de que la verdadera justicia en el país ha tardado en llegar.

Palabras clave: Derechos Humanos, justicia de transición, defensa transnacional la transformación democrática, jurisdicción universal.

\section{Introduction $^{1}$}

For the past 40 years Chile has in many ways been a most unlikely case. ${ }^{2}$ In comparative terms, it is a relatively small country of approximately 17 million people that has undergone a series of significant political transformations that have garnered disproportionate attention from external actors. First, the military coup of 11 September 1973 meant that Chile joined other South American countries that had suffered the breakdown of democracy, such as Brazil in 1964, Argentina in 1966, Peru in 1968, and Uruguay in 1973; however, in many ways, the Chilean case was more unexpected given its comparably longer tradition of democracy than many of its neighbours in the region (Valenzuela 1989:160; Huneeus 2007: xxi). Second, the Pinochet dictatorship had an unusual commitment to a certain formal sense of legality that manifested itself in a series of Constitutional Acts and a publicly supported Constitution in 1980 that was followed by a publicly supported and orderly transition in the 1988 plebiscite in which the 'No' campaign was surprisingly successful (Valenzuela 1989; Foweraker and Landman 1997; Huneeus 2007: 149151). Third, despite theories and arguments to the contrary, social mobilization

1 Autobiographically, the case of Chile has been with me for my entire academic career. I attended a lecture by Arturo Valenzuela in 1986 while at the University of Pennsylvania, wrote my senior paper on Chile, studied with Arturo Valenzuela at Georgetown, and then supervised one his students Jaime Baeza Freer for his PhD at the University of Essex. Jaime kindly hosted me in Santiago and Concepción and introduced me to former President Patricio Aylwin in 2010. Chile has featured in my academic work throughout this period, and the University of Essex has been host to many Chilean exiles (and their children) and will host a number of events during autumn 2013 to commemorate the 40th anniversary of the military coup of 11 September 1973.

2 It is also possible to refer to Chile as a 'least likely' case, which has challenged a number of predominant social and political theories about democratic breakdown, authoritarian rule, democratic transition, and transnational advocacy. See Eckstein (1975). In 2004, I referred to Chile as the 'ultimate' case study since its various political trajectories have such relevance for such a wide range of significant questions in comparative politics and human rights (Landman 2004). 
under the conditions of authoritarian rule of the kind under Pinochet was not only possible, but also contributed to the democratic transformation that took place during the 1980s in Chile (see Foweraker and Landman 1997; Hawkins 2002). Fourth, and the focus of this article, the case of Chile represents a focal point for the international human rights movement, which has found increasing success through the mobilization of 'transnational advocacy networks' linking domestic human rights activists with international activists, 'rights-protective' countries (Donnelly 1999), and inter-governmental organisations (Roht-Arriaza 2005; Spooner 2011). The increasing success of this movement and the advent of the 'justice cascade' (Sikkink 2011) has made it increasingly difficult for heads of state to carry out human rights abuses with impunity while in power and to escape justice once they are out of power (see Risse, Ropp and Sikkink 1999; 2013). The article argues that the impact of the Chilean case is enduring even today and provides a 'dual lesson' with respect to (a) the culpability of dictators for their past crimes (as evidenced in the recent verdicts against Charles Taylor in Sierra Leone and General Ríos Montt in Guatemala) and (b) the appeal of dictators as 'correctives' to political instability of the kind seen in Egypt since the overthrow of Hosni Mubarak.

\section{Human Rights in Chile}

Over the last 40 years Chile experienced a pattern in the violation of civil and political rights that was relatively severe in the early years of the Pinochet regime, that modulated from outright killings and disappearances in the 1970s to arbitrary detention and torture in the 1980s, to dramatic improvements in human rights protection after the plebiscite and throughout the period of democratic consolidation in the 1990s. The consolidation of authoritarian rule in Chile under the leadership of President Pinochet was achieved relatively quickly through a series of Constitutional Acts combined with the creation of an increasingly powerful internal security agency (most notably the National Intelligence Directorate, Dirección de Inteligencia National, DINA), which was built on an initially highly repressive set of policies that led to widespread extra-judicial killings, exile, disappearances, torture and other cruel and inhuman treatment often carried out in secret (see Valenzuela and Valenzuela 1986; Constable andValenzuela 1993; Kornbluh 2004; Huneeus 2007). The repression brought with it initially an attempt to document human rights abuses most notably by theVicariate of Solidarity (Vicaría de la Solidaridad) followed by increasing forms of social mobilization, which peaked during the economic crisis of the early 1980s and were subsequently quashed with by the declaration of various states of siege between 
1984 and 1987. ${ }^{3}$ Social mobilisation returned to Chile with the 1988 Plebiscite as support for the 'No' Campaign grew, and the 1989 democratic transition was relatively peaceful and brought with it a dramatic decrease in human rights abuse. Continued contestation over social policy, indigenous rights, educational issues among others have produced some repression but nothing compared to the policies of the Pinochet regime between 1973 and 1990.

Using different 'standards-based' measures of human rights (Jabine and Claude 1992; Landman and Carvalho 2009), it is possible to see the general patterns of evolution in the abuse and protection of civil and political rights from the 1970s until 2011. Figure 1 depicts the 'political terror scale' from 1976 until 2010, which is a five-point scale that measures the abuse of 'rights to personal integrity' (the use of exile, arbitrary detention, torture and extra-judicial killings) coded from both Amnesty International annual reports and the US State Department Annual Country Reports (see Poe and Tate 1994; Landman and Carvalho 2009). ${ }^{4}$ Both scales show an evolution of rights protection (or violation depending on one's point of view) during the period that is consistent with the brief historical overview presented above. The overall trend line shows an overall decrease in the level of human rights abuse captured by this measure. Figure 2 depicts the Cingranelli and Richards (CIRI) 'physical integrity rights index' from 1981 to 2010, which is a scale that measures a similar set of rights as the political terror scale using the US State Department Country Reports. ${ }^{5}$ Again, as in the trends depicted by the political terror scale, CIRI data show the pattern of human rights protection since the 1980s and periods of transition and consolidation, which overall has been positive. With respect to other countries in the region, human rights abuse was arguably higher than Chile during periods of military rule in Argentina (19761982) and Uruguay (1973- 1985), and arguably lower than Chile in the case of military rule in Brazil (1964-1985).

3 The transitory articles of the 1980 Constitution allowed for the use of 'states of exception', which were variously invoked in the 1980s; something that is quite typical throughout Latin America (Loveman 1993).

4 Data available from www.politicalterrorscale.org and www.humanrightsatlas.org

5 Data available from www.humanrightsdata.com and www.humanrightsatlas.org 
Figure 1

Political Terror Scale for Chile, 1976-2011

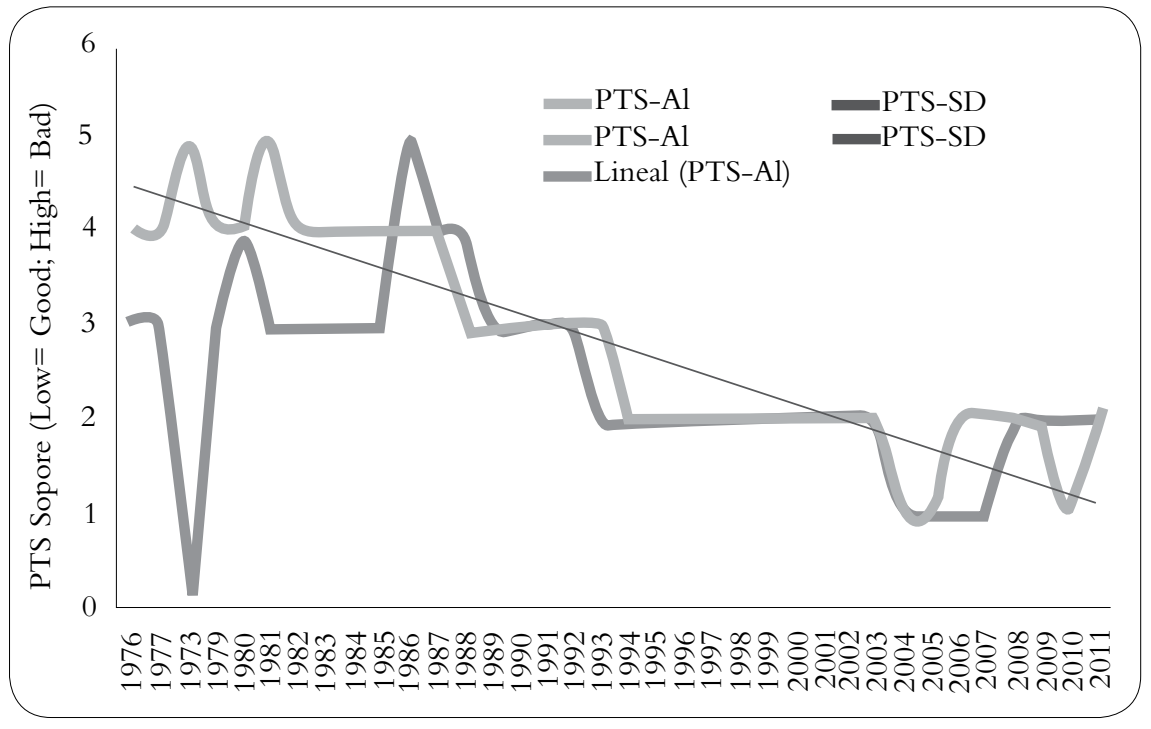

Figure 2

Cingranelli and Richards Physical Integrity Rights for Chile, 1981-2010

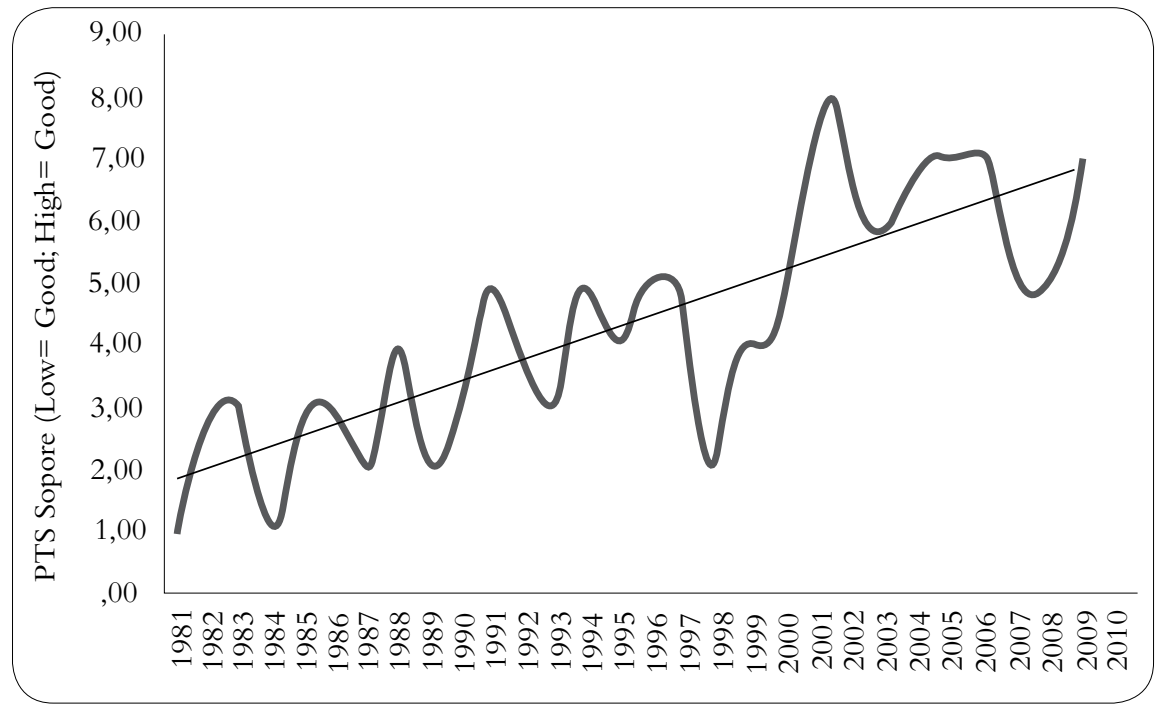

While these measures allow for the mapping of broad patterns in the relative protection of certain human rights, they of course say nothing of the human stories 
behind the abuses that were committed. Interestingly, Chile was one of the first countries in the world to undertake a process of truth and reconciliation and stands alongside Argentina and South Africa as the first generation of such processes ${ }^{6}$, which used a formal body with a particular mandate to uncover past wrongs (see Hayner 1994, 2002, 2010; Landman 2006; Landman and Carvalho 2009). As an early example of a truth and justice process, Chile stands out as having had an official standing with a legally recognised commission (Comision Nacional de Verdad $y$ Reconciliación, or 'Rettig Report'), but its mandate was particularly narrow and focussed on that set of cases that could be documented through the identification of actual physical remains of victims (as opposed to the systematic analysis of narrative accounts of rights violations used in subsequent truth commissions, e.g. in South Africa, Peru, East Timor, Sierra Leone).Thus, official lists of the victims from the truth and justice process include a total of 2,774 human rights victims and 423 victims of political violence (see, e.g. Huneeus 2007: 5). These figures grossly underestimate the real total of victims, particularly since many in Chile simply 'disappeared' during the Pinochet regime; a problem that confronts all data projects seeking to provide accounts of past wrongs (see Ball, Spirer, and Spirer 2000; Landman 2006; Seybolt, Aronson and Fishoff 2013). ${ }^{7}$ The gross under-representation of victims means that any sense of 'truth' has been incomplete; that accounts of the depth and breadth of real human suffering that took place during the dictatorship have found expression through different means (documentation projects, memory museums such as the site atVilla Grimaldi in Santiago, novels, films, and non-fiction books); and that any real attempts at reconciliation have not yet been achieved. Official truth processes in Chile have at least acknowledged that past wrongs had occurred and that agents of the regime were responsible; however, any retributive justice has been elusive, even, as we shall see, in the case of Pinochet himself (Spooner 2011: 83).

As part of the military's extraction from power, Pinochet remained the head of the military until 1997, was pronounced 'Senator for Life', and the military guaranteed itself a percentage of foreign exchange to fund its on-going activities (Roht-Arriaza 2005: viii). These and other factors infuriated the victims of Pinochet's time in

${ }^{6}$ The precedent for such bodies was established of course through the Military Tribunal in Nuremberg after the Second World War, but the Chilean Truth and Reconciliation Commission was domestic and did not have prosecution as its main objective. Rather, it was focussed, like many other such subsequent commissions, on establishing a record of what happened during the period of authoritarian rule.

7 Chile had a second commission, the National Commission on Political Imprisonment and Torture (or the Valech Report), which published its findings in 2004 and 2005, which carried with it some reparations to the victims of the Pinochet regime. 
power and significantly undermined any attempts by the Aylwin government to move the process of reconciliation forward (Spooner 2011:91-94). The politics after the authoritarian regime were such that any attempt at pursuing prosecutions was not possible (Roht-Arriaza 2005: viii). Rather, Aylwin apologised on behalf of the previous regime and focused on reparations for the victims; a policy that he saw was dedicated to providing truth and 'as much justice as possible' (Ibid, viii). Absence of official state prosecution of military and security personnel alleged to have been responsible for human rights abuse during the Pinochet years meant that many victims sought redress through the civil courts. Indeed, there were approximately 750 private prosecutions against army, police, air force and naval officers (see Angell 2007: 65). On balance, however, the immediate post-Pinochet years saw an acknowledgement of human rights as an issue, but it was quickly downplayed and dissipated from dominating public discourse. Chile, alongside countries such as Argentina, it would appear, had escaped any serious attempt to redress past wrongs. As Roht-Arriaza (2005: ix) claims:

The Chilean "economic miracle" was held up as a model for the developing world. No suggestions of ad hoc UN Criminal Tribunals here. A controlled and limited transition from dictatorship to democracy, based on pacts among elites, partial truths, and very partial justice, seemed to have become the template for other Latin American countries, and even for other continents. End of story.

As we shall see, however, Chile nor Pinochet existed in a vacuum. Developments at the international level and a legal arrangement between Spain and the United Kingdom would lead to a dramatic set of events that once again thrust Chile and Pinochet in the limelight; the outcome of which would change international criminal law forever ironically at a time when the world's most established democracies were undermining their own human rights commitments in the name of the 'war on terror' (see Sands 2006; Landman 2013). Before examining the arrest, detention and impact of the Pinochet case on the international human rights movement, it is first necessary to locate Chile within the larger normative developments in human rights that began with the passage of the 1948 Universal Declaration of Human Rights.

\section{The International Dimensions of Human Rights}

The incomplete nature of reconciliation and retribution in Chile stands in stark contrast to the international attention that it has attracted over the past 40 years. The case itself sits alongside developments in the international law and practice of human rights that arguably took more concrete form with the promulgation of the 1948 Universal 
Declaration of Human Rights. Largely seen as a response to the atrocities committed during World War II, the Universal Declaration put a stake in the ground in articulating a set of universal human rights (as opposed to nationally grounded citizenship rights) across thirty articles that ought to be protected. The ideas and assertions found within the Universal Declaration were fortified through international law in the 1960s with the passage of the 1966 International Covenant on Civil and Political Rights and the 1966 International Covenant on Economic, Social and Cultural Rights, which along with the Universal Declaration formed the International Bill of Human Rights. These instruments that comprise the International Bill of Human Rights have been accompanied by an increasing number of international covenants on more specific rights issues, including racial discrimination (1966), women's rights (1979), torture (1984), children's rights (1989), migrant workers (1990), disability (2006), and enforced disappearances (2006). In similar fashion, the 1969 American Convention of Human Rights (ACHR) brought similar sets of formal rights protections and obligations to countries in Latin America, and it too was followed by additional human rights instruments that guarantee the protection of human rights throughout the InterAmerican system. These international and regional human rights treaties have been complemented with the 1998 Rome Statute for the International Criminal Court (entered into force in 2002). Described as the international institutionalisation of criminal liability' (Falk 2000), the establishment of the International Criminal Court in many ways represents the culmination of over 80 years of advocacy around the issue of 'universal jurisdiction'; a legal principle that allows states or international organizations to claim criminal jurisdiction over an accused person regardless of where the alleged crime was committed. The principle also applies to the person regardless of his or her nationality, country of residence, or any other relation with the entity that is carrying out the prosecution.

The developments in human rights in Chile outlined above thus sit alongside this larger normative progression at the international level. Chile was arguably a stable democracy when the Universal Declaration was passed and remained so until the three years leading up to the 1973 military coup, which occurred after the promulgation of the International Bill of Human Rights. Chile has also participated in the normative proliferation of human rights instruments throughout the Pinochet and post-Pinochet years. Table 1 lists the major international and regional human rights treaties along with Chile's record of ratification over the last 40 years. The table shows that Chile ratified the major international human rights instruments before they came into force, but ratified the American Convention and the Rome 
Statute after they had come into force. ${ }^{8}$ More importantly for the concerns of this article, the two 1966 international covenants for human rights (ICCPR and ICESCR) did not actually came into force until 1976; a full three years after the military coup that brought Pinochet to power.

Table 1

Chile's Ratification of Major International Human Rights Treaties

\begin{tabular}{|c|c|c|}
\hline Name of Human Rights Treaty & Ratification1 & $\begin{array}{l}\text { Entry into } \\
\text { Force }\end{array}$ \\
\hline $\begin{array}{l}1966 \text { International Covenant on Civil and Political } \\
\text { Rights (ICCPR) }\end{array}$ & $\begin{array}{l}10 \text { February } \\
1972\end{array}$ & $\begin{array}{l}23 \text { March } \\
1976\end{array}$ \\
\hline $\begin{array}{l}1966 \text { International Covenant on Economic, Social, and } \\
\text { Cultural Rights (ICESCR) }\end{array}$ & $\begin{array}{l}9 \text { February } \\
1972\end{array}$ & $\begin{array}{l}3 \text { January } \\
1976\end{array}$ \\
\hline $\begin{array}{l}1966 \text { Convention on the Elimination of All Forms of } \\
\text { Racial Discrimination (CERD) }\end{array}$ & $\begin{array}{l}20 \text { October } \\
1971\end{array}$ & $\begin{array}{l}19 \text { November } \\
1971\end{array}$ \\
\hline $\begin{array}{l}1979 \text { Convention on the Elimination of all forms of } \\
\text { Discrimination Against Women (CEDAW) }\end{array}$ & $\begin{array}{l}7 \text { December } \\
1989\end{array}$ & $\begin{array}{c}6 \text { January } \\
1990\end{array}$ \\
\hline $\begin{array}{c}1984 \text { Convention against Torture and Other } \\
\text { Cruel, Inhuman or Degrading Treatment } \\
\text { or Punishment (CAT) }\end{array}$ & $\begin{array}{l}30 \text { September } \\
1988\end{array}$ & $\begin{array}{l}30 \text { October } \\
1988\end{array}$ \\
\hline 1989 Convention on the Rights of the Child (CRC) & $\begin{array}{l}13 \text { August } \\
1990\end{array}$ & $\begin{array}{l}12 \text { September } \\
1990\end{array}$ \\
\hline 1990 Convention on Migrant Workers (CMW) & $\begin{array}{l}21 \text { March } \\
2005\end{array}$ & 21 June 2005 \\
\hline $\begin{array}{l}2006 \text { Convention on the Rights of People } \\
\text { with Disabilities (CRPD) }\end{array}$ & $\begin{array}{l}29 \text { July } \\
2008\end{array}$ & $\begin{array}{l}29 \text { August } \\
2008\end{array}$ \\
\hline $\begin{array}{l}2006 \text { Convention for the Protection of All Persons } \\
\text { from Enforced Disappearance (CED) }\end{array}$ & $\begin{array}{l}8 \text { December } \\
2009 \\
\end{array}$ & $\begin{array}{l}23 \text { December } \\
2010\end{array}$ \\
\hline $\begin{array}{c}1969 \text { American Convention on Human } \\
\text { Rights (ACHR) }\end{array}$ & $\begin{array}{l}10 \text { August } \\
1990\end{array}$ & 18 July 1978 \\
\hline $\begin{array}{c}1998 \text { Rome Statute of the International Criminal } \\
\text { Court (ICC) }\end{array}$ & 29 June & 1 July 2002 \\
\hline
\end{tabular}

1Ratification includes ratification, accession or succession. 2Chile signed the Rome statute on 11 September 1998. Source: www.bayefsky.com

8 Symbolically, Chile signed the Rome Statute on 11 September 1998, the 25th Anniversary of the military coup; however, the Government was wary of international authority and the application of universal jurisdiction, since it needed to balance justice with national reconciliation; a point which was made very clear in a letter from the Chilean Foreign Minister to Kofi Annan, the UN Secretary General on 22 December 1998 (see Brotóns 2003: 231). 
Chile is thus an early 'hard case' for the international 'regime' of human rights, which at this time was exceedingly weak and lacking in strong enforcement powers (see Donnelly 1986; Landman 2005a). Its subsequent development through more treaties and greater participation from countries around the world (see Landman 2005a) coupled with a growing set of 'transnational advocacy networks' (Risse, Ropp and Sikkink 1999; Sikkink 2011) meant that Chile found itself under increasing domestic and international pressure for the human rights abuses being committed by the Pinochet regime. In a careful analysis of this pressure alongside an examination of over 45,000 internal military documents, Hawkins (2002) shows that a particular 'rule-oriented' faction (itself a function of Chile's strong legal tradition) within the regime had become increasingly concerned over this pressure, and was instrumental in opening the way for the reforms that led to the plebiscite and eventual democratization. Thus in addition to patterns of popular mobilization that challenged the regime's grip on power (see Foweraker and Landman 1997), there was also a significant international dimension to the mobilization that increasingly led to credibility problems of the regime and drove a wedge between factions within the regime (Hawkins, 2002).

These developments at the international and domestic level with respect to the de jure protection of human rights, the de facto realisation of human rights, and the pressure to close the gap between the two have featured widely in the literature on human rights 'compliance' (see Risse, Ropp and Sikkink 1999; Landman 2005a; Smith-Cannoy 2012; Risse, Ropp and Sikkink 2013). In some cases, analysis has been a little too optimistic about the necessary association between human rights advocacy and human rights improvements (Ropp and Sikkink 1999), while in others, there is a recognition of the piecemeal, iterative and potentially regressive nature of the relationship, where moments of rights achievement can be reversed easily (see Foweraker and Landman 1997; Hawkins 2002; Landman 2013). Indeed the cycle of protest during the Chilean economic crisis in the early 1980s was met by a harsh declaration of a state of siege (1984-1987) in which thousands of students, popular actors and other dissidents were arbitrarily detained and in many cases tortured (see Foweraker and Landman 1997; Huneeus 2007: 54-55). This use of repression did not go unnoticed of course, and after Pinochet left political power in his new role of head of the military and 'Senator for Life', he was soon to be shocked by the power of the international human rights movement and world of international law that had moved on considerably since the time he had taken power in 1973. 


\section{The Pinochet Case and Universal Jurisdiction}

On 16 October 1998, British police, acting on an extradition request from a Spanish judge arrested and detained Pinochet, who had come to the UK for a back operation in a private hospital. ${ }^{9}$ His detention became relatively prolonged as he remained under house arrest for over a year and half, while the Law Lords debated the merits of his detention and more importantly the merits of the legal case against a former head of state accused of committing human rights abuses. Judge Baltasar Garzón argued that the state security apparatus under the command of Pinochet had committed human rights violations against Spanish citizens, and that since Britain and Spain were party to a bi-lateral extradition treaty, Pinochet could be detained to answer these charges in a Spanish court. ${ }^{10}$ This inventive legal argument carried enough weight to lead the British authorities to detain Pinochet. The detention sent shockwaves around the world even before any resolution of the case. As Sikkink (2012: 121) notes, '[e]ven the most ardent advocates of accountability didn't really believe such an arrest was feasible. The international lawyers knew it was legally possible, but no one believed it was politically possible.'The political impossibility stemmed not only from friendly relations with Margaret Thatcher and political right in the UK, but Chile was a staunch ally for Britain in the 1983 Falklands/Malvinas war, and many believed that he had saved the Chilean economy from ruin (see below) (Roht-Arriaza 2005: 36).

With Pinochet's arrest and detention, Chile was once again an unlikely case that was thrust to the centre of international attention. Judge Garzón charged Pinochet with genocide and terrorism partly based on his rule within Chile and partly on his role in 'Operation Condor', an alliance of Southern Cone dictatorships that had detained, disappeared, tortured, and executed political dissidents through transnational cooperation and that had enjoyed support from the CIA (see Dinges 2004; Landman 2004). The key question initially was whether Pinochet had diplomatic immunity as a former head of state. The fact that he was on a private visit to the UK helped his

9 On this day, I was en route to Venice to teach a democratization module as part of the European Master's Degree in Human Rights and Democratization. I was greeted in Venice by students and staff who shared this extraordinary news. At first, my jaw dropped as I could not believe the British authorities would arrest a former head of state, particularly one that had strong relations with Margaret Thatcher and was a regular visitor to the UK. As the story unfolded over the next few days it became clear that the UK police had the authority to detain Pinochet, and the ensuing case which lasted for over a year and half would yield a major victory for the international human rights and international justice movements.

10 The foundation for the detention was set in an earlier suit filed in Spain in June 1996 against Pinochet and his accomplices for genocide, terrorism and torture (Roht-Arriaza 2005: 1-2). 
opponents make the case for his arrest, but once detained, immunity claims were filed in his defence. Initial hearings concluded that the legal principles in the Genocide Convention had not been translated into English Law and that although Pinochet had carried immoral acts, they nonetheless were part of his 'official functions' as head of state and therefore fell under the principle of state sovereignty. The only recourse was to make an appeal to the House of Lords (Davis 2003; Roht-Arriaza 2005: 44).

Law can both facilitate and hinder developments in human rights. Strict legal principles, applicability, and jurisdiction can often confound attempts to advance human rights (e.g. the annulment of the Ríos Montt judgment in 2013, see below), while patient application of all available legal principles can chip away at long held practices and assertions of state sovereignty that mask crimes against human and other egregious violations of human rights. Pinochet's defence rested on his immunity from prosecution as a former head of state. Advocates for extradition and prosecution were based on a jus cogens argument ${ }^{11}$ that some crimes, such as torture are simply too egregious to ignore and the defendant cannot hide behind principles of diplomatic immunity.The deliberations in the House of Lords centred on all these legal questions. The Law Lords agreed that torture is a special case of egregious crime, but the UK had only incorporated the principles found in the 1984 Convention on Torture in the Criminal Justice Act 1988, and thus could only focus on those crimes committed from 1988. While this much narrower focus (indeed, the year of the plebiscite) invalidated most of the original charges against Pinochet, the decision to extradite him to Spain could nevertheless be upheld. Significant contestation ensued about whether (a) he should be extradited to Spain (e.g. George Bush and Margaret Thatcher said no, human rights groups and Mary Robinson, UN High Commissioner for Human Rights said yes) or (b) he should be allowed to return to Chile. In the end, the decision rested with Home Secretary Jack Straw, who in March 2000 decided that for reasons of ill health, Pinochet should be permitted to return home.

Pinochet's return home was met with outcry and dismay from many within the human rights community. It was politically expedient for both the New Labour Government in Britain and the Concertación Government of Eduardo Frei RuizTagle, since neither government wanted to be embroiled in a prolonged diplomatic and legal wrangle over the fate of the former dictator. It is very telling now to observe the diplomatic rows over Julian Assange and his asylum in the Embassy of

11 Jus cogens means 'compelling law' or a peremptory norm, which refers to certain fundamental and overriding principles of international law, from which no derogation is ever permitted (Brownlie 1998). 
Ecuador and Edward Snowden and his asylum in Russia. Neither individual is a former dictator, nor have they committed crimes against humanity (some believe no crimes at all have been committed), but imagine the politics of extradition of a former head of state by Britain to a third country and then the trial of that head of state in the third country. Straw's decision neatly avoided this scenario while at the same time upholding the decision to extradite. The short term dismay at not seeing the former dictator on trial in Spain was balanced against a longer term legal victory that many have argued is the most important in the field of international human rights and humanitarian law since the Nuremberg Trials (Davis 2003; Roht-Arriaza 2005; Spooner 2011; Sikkink 2011).

The focus of this article is on the international impact of these events and thus is not particularly concerned with Pinochet's return to Chile, where he was variously placed under house arrest and liberation until his death on 10 December 2006. The facts of the case are that Pinochet escaped prosecution abroad and at home, and justice was not served. But there has been much broader impact of the case for the international human rights movement and for the advocates of universal jurisdiction. The Law Lords decision on extradition provided a boost to this principle and demonstrated to other countries and other cases of crimes against humanity that transnational prosecution of alleged war criminals, dictators, and state agents from repressive regimes could be attempted. Indeed, the courts in Spain and Belgium, for example, started to receive new cases, some of which were dismissed, but some of which showed more promise, including cases on Guatemala, Suriname, Chad, Congo, and Israel (see Roht-Arriaza 2005: 170-191). The increased attractiveness of transnational prosecutions also provided political leverage and the language of rights for advocates and victims groups to mobilise and seek accountability for offenders around the world. The special tribunals for the Former Yugoslavia, Rwanda and the Special Court for Sierra Leone also benefitted, albeit a bit more indirectly, from the events surrounding the Pinochet case. In Guatemala, it is reported that General Ríos Montt, former president and alleged war criminal was at least contemplating the events in London at the time and despite publicly declaring he was not concerned about travelling abroad, he has nonetheless never left his country (Sikkink 2011: 175-176). Indeed, in 2013, Ríos Montt was tried by a domestic court for genocide for his role in the systematic killing of indigenous people over an 18-month period during 1982 and 1983. Even though the court annulled its 10 May 2013 guilty vedict, 
the principle of immunity of former heads of state challenged by the Pinochet case helped fortify many of the arguments in the case against Ríos Montt. ${ }^{12}$

The irony of these developments is that at the same time that the Pinochet case was buttressing the human rights movement, well-established democracies in Europe and North America were passing anti-terror legislation that significantly undermined long-held rights commitments. For example, the Patriot Act in the United States and various anti-terror acts in the UK increased and centralised power in the executive branch, allowed for the indefinite detention of terror suspects without charge, and greatly enhanced the ability of governments to use stop and search powers and interfere with the private correspondence and financial activities of ordinary citizens suspected of being involved in terrorist activity (see Sands 2006; Lustik 2006; Brysk and Shafir 2007; Landman 2007a, 2007b). The arguments for tightening security powers of the state were ominously the same as those used by the authoritarian regimes of the Southern Cone that were part of Operation Condor. Dubbed the "first war on terror," the Condor Years lasted from 1973 to 1980, during which the military regimes of Argentina, Brazil, Uruguay, Paraguay, and Bolivia were arguably at their most brutal. The alliance sought to "track down "terrorists" of all nationalities, wherever they resided' (Dinges 2004: 4), and an 'extraordinary list of military and political leaders from the countries of southern South America lost their lives or were targeted for assassination' (Dinges 2004: 1). While the activities were initially limited to Latin American countries, from 1976 onwards, Chile, Argentina, and Uruguay created multinational teams that carried out operations outside Latin America, including the Letelier bombing ${ }^{13}$ and two other foreign assassination attempts. The post-9/11 'war on terror' and its associated by-product of human rights abuse are eerily reflected in the Condor activities, where the hunt for subversion leads to the curbing of liberties, moral relativism, complete disregard for hard fought international standards, and the persistence of impunity. These positive and negative developments with respect to human rights demonstrate that both sides of the Pinochet legacy continue to have an impact far beyond the confines of Chile.

12 For ongoing analysis of the trial, see http://www.riosmontt-trial.org. In particular, see the analysis of the judgment from Roht-Arriaza and Kemp: http://www.riosmontt-trial.org/2013/06/the-rios-monttjudgment-in-light-of-international-law/ . It is expected that a new trial will be held in April 2014.

13 Olando Letelier was a Chilean economist and socialist living in Washington DC who was killed by a car bomb on 21 September 1976. Dinges (2004) shows that the assassination was carried out under the auspices of Operation Condor. 


\section{Conclusions and Implications}

This article has used the $40^{\text {th }}$ Anniversary of the 1973 military coup in Chile as a moment to reflect on the disproportionate impact the case has had on the advance of human rights. The coup itself and the quick consolidation of authoritarian rule under Pinochet came at a time when the international and inter-American human rights regimes were notoriously weak and at best 'promotional' (Donnelly 1986). Yet, the atrocities that were committed increasingly galvanised human rights activists inside and outside Chile in ways that would contribute to significant advances in human rights protection around the world. The international regime became increasingly fortified, human rights NGOs proliferated and strengthened, and human rights arguments found tangible expression in live cases that were unfolding before the world's eyes. Pinochet's arrest, detention and extradition decision came at a time when the International Criminal Court came into force and human rights activists found an alternative path to pursue justice. The Pinochet case and other rights achievements provided a grammar for struggle against the forces of repression and reminded the world that human rights can indeed act as the 'bulwarks against the permanent threat of human evil' (Mendus 1995). As Roht-Arriza (2005: 224) argues:

In the end, it was ordinary people, acting mostly on their own time and their own dime, who made the Pinochet cases a landmark in international law and a symbol for both dictators and génocidaires and for their survivors. It will be ordinary people, organised into various and ever-changing groups, who will hold states to their promises to respect and ensure basic human rights. And it is ordinary people who, again and again and again, until it's not necessary any more, will demand justice, of the national and international and transnational kind.

These otherwise positive developments must be balanced, however, with the precariousness of human rights achievements (Reiff 1999; Landman 2013). Pinochet did not return home to receive justice and many democracies at the same time had become attracted to the argument that when under threat, security trumps rights. The world's main defenders of human rights and promoters of democracy have looked inward after the 'other' 11 September and pursued security policies that continue to undermine the quality of democracy and the sanctity of human rights. The Abu Ghraib scandal, Guantánamo Bay, and the National Security Agency scandal all demonstrate that basic freedoms and rights require vigilance and defence against what appears to be easy authoritarian temptations (cf Revel 1978). While there have been quiet judicial revolutions in both the UK and US that are beginning to roll back 
the more draconian aspects of anti-terror policies, it would have been inconceivable before $9 / 11$ to have imagined the kinds of events that have shocked the world.

This 'dual lesson' from Chile (human rights can be won and easily lost) is instructive for other struggles against oppression that are taking place. The Arab Spring mobilizations of late 2010 and early 2011 showed that even within one of the last bastions of authoritarianism, social mobilization from ordinary people was not only possible but could in the cases of Egypt and Tunisia lead to the toppling of authoritarian governments. Disaffected younger generations that have not benefitted from the highly concentrated and 'sultanistic' forms of authoritarianism in the region began by articulating economic demands that soon escalated into general demands for regime change (Landman 2013). Public manifestations became more nationalised through social media and other forms of communication (see Breuer, Landman and Farquhar (2013) and led to the ousting of the Ben Ali Regime in Tunisia and the Mubarak regime in Egypt. With the 2 July 2013 'coup that never was' in Egypt that ousted democratically elected President Morsi, there has been renewed attention about the role of the military in politics that has once again invoked the memory of Augusto Pinochet. I was struck by an extraordinary response to the military coup against Morsi that appeared in the Wall Street Journal:

Egyptians would be lucky if their new ruling generals turn out to be in the mold of Chile's Augusto Pinochet, who took power amid chaos but hired free-market reformers and midwifed a transition to democracy. ${ }^{14}$

This quote aptly demonstrates not only a complete misreading of Chilean history and the period of Pinochet's rule, but also the continuous need for human rights scholars and practitioners to document, research and struggle against the forces of oppression wherever they may appear in the world. In the event, the General Sisi period of rule in Egypt has also included the use of repression that is emblematic of the Pinochet years, where the 14 August 2013 clearing of pro-Morsi forces led to a large number of casualties at the hands of the Egyptian military. The lesson from these events in Egypt (like so many lessons in history) is very clear with respect to the article in the Wall Street Journal: be careful what you wish for. The case of Chile under Pinochet has affected so many lives that in many ways has been disproportionate to the size of the country and the relatively short period of time that Pinochet was in

14 'After the Coup in Cairo,'Wall Street Journal, 4 July 2010; http://online.wsj.com/article/SB10001 424127887324399404578583932317286550 
power, but for the lives that it has touched, either directly or indirectly, the case must never be forgotten and its lessons for human rights must be shared forever.

\section{References}

Ball, P., Spirer, H. and Spirer, L. (2000) Making the Case: Investigating Large Scale Human Rights Violations Using Information Systems and Data Analysis. Washington, DC: American Association for the Advancement of Science.

Brownlie, Ian (1998). Principles of Public International Law, Oxford: Oxford University Press.

Breuer, Anita, Landman, Todd and Farquhar, Dorothea (2012). Social Media and Protest Mobilization: Evidence from the Tunisian Revolution, Paper prepared for the 4th European Communication Conference for the European Communication Research and Education Association (ECREA), Istanbul, Turkey, 24-27 October 2012.

Brysk, A. and Shafir, G.(eds) (2007). National Insecurity and Human Rights: Democracies Debate Counterterrorism, Berkeley: University of California Press.

Constable, Pamela and Valenzuela, Arturo (1991). A Nation of Enemies: Chile Under Pinochet, New York: Norton.

Dinges, John (2004). The Condor Years: How Pinochet and His Allies Brought Terrorism to Three Continents, New York: The New Press.

Donnelly, J. (1986). "International human rights: A regime analysis". International Organization, Vol. 40, $\mathrm{N}^{\circ} 3$, pp.599-642.

Donnelly, J. (1999). "Democracy, development, and human rights". Human Rights Quarterly, Vol. 21, N³, pp. 608-632.

Eckstein, Harry (1975). "Case-study and Theory in Political Science". In F.I. Greenstein and N.S. Polsby (eds) Handbook of Political Science, Vol. 7: Strategies of Inquiry. Reading, MA: Addison-Wesley, 79-137.

Falk, R. (2000). Human Rights Horizons: The Pursuit of Justice in a Globalizing World. London: Routledge.

Foweraker, J. and Landman T. (1997). Citizenship Rights and Social Movements: A Comparative and Statistical Analysis. Oxford: Oxford University Press.

Hawkins, Darren (2002). International Human Rights and Authoritarian Rule in Chile, Lincoln: University of Nebraska Press.

Hayner, P.B. (1994) "Fifteen Truth Commissions 1974-1994:A Comparative Study". Human Rights Quarterly,Vol. 16, N4, pp.597-655. 
Hayner, P. B. (2002). Unspeakable Truths: Facing the Challenge of Truth Commissions, London: Routledge.

Huneeus, Carlos (2006). The Pinochet Regime, Boulder: Lynne Reiner.

Kornbluh, Peter (2003). The Pinochet File: A Declassified Dossier on Atrocity and Accountability, New York: The New Press.

Landman, Todd (2004). \#Pinochet's Chile: The United States, Human Rights, and International Terrorism”. Human Rights and Human Welfare,Vol.4, Nº1, pp.91-99.

Landman, T. (2005a). Protecting Human Rights: A Comparative Study. Washington D.C.: Georgetown University Press.

Landman, T. (2005b) "Review article:The political science of human rights". British Journal of Political Science,Vol.35, N³, pp.549-572.

Landman, Todd (2006). Studying Human Rights. London and New York: Routledge.

Landman, Todd (2013). Human Rights and Democracy: The Precarious Triumph of Ideals. London: Bloomsbury.

Landman, Todd and Carvalho, Edzia (2009). Measuring Human Rights, London: Routledge.

Loveman, Brian (1993). The Constitution of Tyranny: Regimes of Exception in Spanish America, Pittsburgh: University of Pittsburgh Press.

Poe, S.C. and Tate, C.N. (1994). "Repression of Human Rights to Personal Integrity in the 1980s: A Global Analysis"American Political Science Review,Vol. 88, №4, pp. 853-872.

Reiff, David (1999). 'The Precarious Triumph of Human Rights', New York Times, 8 August; http://www.nytimes.com/1999/08/08/magazine/the-precarious-triumphof-human-rights.html.

Revel, Jean Francois (1978). The Totalitarian Temptation. New York: Penguin.

Risse, T., Ropp, S.C., Sikkink, K. (eds) (1999). The Power of Human Rights: International Norms and Domestic Change. Cambridge: Cambridge University Press

Risse, T., Ropp, S.C., Sikkink, K. (eds) (2013).The Persistent Power of Human Rights: From Commitment to Compliance. Cambridge: Cambridge University Press.

Roht-Arriaza, Noami (2005).The Pinochet Effect:Transnational Justice in the Age of Human Rights. Philadelphia: University of Pennsylvania Press.

Sands, Philippe (2006). Lawless World America and the Making and Breaking of Global Rules. New York: Penguin 
Seybolt, Taylor, Aronson, Jay and Fishoff, Baruch (eds) (2013). Counting Civilian Casualties: An Introduction to Recording and Estimating Nonmilitary Deaths in Conflict. Oxford: Oxford University Press.

Sikkink, Kathryn (2011). The Justice Cascade: How Human Rights Prosecutions Are Changing World Politics. New York: Norton.

Smith-Cannoy, Heather (2012). Insincere Commitments: Human Rights Treaties, Abusive States and Citizen Activism, Washington DC: Georgetown University Press.

Spooner, Mary Helen (2011). The General's Slow Retreat: Chile After Pinochet. Berkeley: University of California Press.

Valenzuela, Arturo (1989). "Chile: Origins, Consolidation, and Breakdown of a Democratic Regime”. En Larry Diamond, Juan Linz, and Seymour Martin Lipset (eds) Democracy in Developing Countries: Latin America. Baltimore:Johns Hopkins University Press, 159-206.

Valenzuela, Arturo and Valenzuela, Samuel (eds) (1986). Military Rule in Chile: Dictatorship and Oppositions, Baltimore: Johns Hopkins University Press. 
